\title{
Effects of binary seed mixtures of ryegrass, cocksfoot and tall fescue on pasture production
}

\author{
D.R. STEVENS ${ }^{1}$ and M.J. HICKEY ${ }^{2}$ \\ ${ }^{1}$ AgResearch Invermay, Private Bag 50034, Mosgiel, New Zealand \\ ${ }^{2}$ AgResearch Grasslands, Private Bag 11008, Palmerston North, New Zealand \\ ${ }^{1}$ stevensd@agresearch.cri.nz
}

\begin{abstract}
This study measured total dry matter production and botanical composition of binary mixtures of cocksfoot (Dactylis glomerata), ryegrass (Lolium perenne) or tall fescue (Festuca arundinacea), as a replacement series in proportions of 100:0, 75:25, 50:50, 25:75 and 0:100 from June 1987 until May 1993. The binary mixtures were sown in March 1986 with white clover, on an occasionally drought affected Kaweku silt loam, with an average annual rainfall of $750 \mathrm{~mm}$ near Riversdale, in Southland. Mixtures with ryegrass were allowed a 6-month establishment period before ryegrass was overdrilled in early October 1986. Total yields of ryegrass/cocksfoot mixtures increased as ryegrass seeding rate increased. Clover yields were generally unaffected. Mixtures of cocksfoot/tall fescue produced more sown grass than either species sown alone. This lowered clover and other grass yields, resulting in no total dry matter yield improvement in mixtures compared to pure sowings. Tall fescue/ ryegrass mixtures were competitive in winter and spring with lower total yields than either species sown alone. This competition also lowered other grass yields. During summer and autumn the total production increased as the amount of ryegrass increased. Seed mixtures with two perennial temperate pasture grasses did not provide any extra pasture production in a cool temperate environment under infrequent hard grazing management. The best choice for the region would be the grass that provided the greatest dry matter yield. Other components such as clover may be reduced when mixing grasses.
\end{abstract}

Keywords: cocksfoot, competition, Dactylis glomerata, Festuca arundinacea, Lolium perenne, mixtures, pasture yield, replacement series, ryegrass, tall fescue, white clover

\section{Introduction}

The use of pastures sown with several grass and legume species has been a practice long associated with grassland farming (Charlton 1991). The concept is that a balance of pasture species will be reached that produce well under the conditions that prevail in each microclimate across each field. Farmers generally sow pasture mixtures of several grasses, often two or more clovers and occasionally an herb such as chicory (Belgrave et al. 1990). There are perceived benefits from each component, such as added drought tolerance from cocksfoot (Vartha 1975), compatible seasonal growth patterns (Sithamparanathan 1979) and persistence under pest attack (French et al. 1983). Drought tolerance is one of the major criteria for the inclusion of other grass species, such as cocksfoot and tall fescue, into ryegrass-based pasture mixtures.

Ryegrass is a dominant part of pastures in the lower South Island of New Zealand (Hook 1979). However, occasional drought and the impact of grass grub (Costelytra zealandica) feature in a perceived lack of persistence of ryegrass in this environment. This experiment investigated the effects of the inclusion of drought and pest tolerant grasses (cocksfoot and tall fescue) with ryegrass on long-term annual pasture production and composition. The hypothesis considered was that a balanced mixture of two pasture grasses would produce more forage in all seasons than a pasture based on a single sown grass. The purpose of this paper is to compare the effects of initial seeding rate on long-term pasture production, so all comparisons are made to the initial seeding rate, rather than subsequent changes in botanical composition.

\section{Materials and methods}

The experiment was sited on a Kaweku soil, prone to waterlogging in winter and drought in summer. The climate is cool temperate or mesothermal (Garnier 1951) with an annual rainfall ranging from 700 to $1000 \mathrm{~mm}$ (NZ Meteorological Service 1970). Northwest fohn winds in late spring and summer help induce periods when soil moisture deficit limits pasture growth (Taylor \& Pohlen 1968).

High endophyte ( $>80 \%$ of seed Neotyphodium lolii infected) perennial ryegrass (Lolium perenne c.v. 'Grasslands Nui'), tall fescue (Festuca arundinacea c.v. 'Grasslands Roa') and cocksfoot (Dactylis 
glomerata c.v. 'Grasslands Wana') were sown in binary mixtures along with white clover (Trifolium repens c.v. 'Grasslands Huia').

A replacement series was used in a randomised block design with four replicates. Each replicate was grazed separately. Each grass was sown either alone or in mixtures comprising of either Ryegrass/Cocksfoot, Cocksfoot/Tall Fescue or Tall Fescue/Ryegrass, in seeding ratios of 25:75, 50:50 or 75:25, a total of 12 treatments. Data analysis used orthogonal contrasts to examine the linear trend and deviations from this as seeding rate changed from 100 to 0 for each mixture. The linear trend indicates that yield changes as components of the mixture change. The deviations indicate whether the mixtures are competitive or compatible. Negative deviations are competitive and positive deviations indicate a compatible relationship. Average annual data was based on winter, spring, summer and autumn beginning on 1 June, 1 September, 1 December and 1 March respectively.

The $3 \mathrm{~m} \times 15 \mathrm{~m}$ plots were broadcast-sown onto a cultivated seedbed in March 1986. The ryegrass component of mixtures was not sown at this time but was direct drilled into the plots in October 1986 to ensure good establishment of the slower establishing cocksfoot and tall fescue. Seeding rates for the $100 \%$ treatments were 18,11 and $36 \mathrm{~kg} / \mathrm{ha}$ for the Ryegrass, Cocksfoot and Tall Fescue treatments respectively being equivalent to 1000 viable seeds sown $/ \mathrm{m}^{2}$. White clover was sown at $3 \mathrm{~kg} / \mathrm{ha}$. The experiment received annual fertiliser top-dressing of $250 \mathrm{~kg} / \mathrm{ha}$ superphosphate (09-0-11) each spring. All replicates were grazed at the same time with grazing occurring when 1500-2000
$\mathrm{kgDM} / \mathrm{ha}$ had accumulated. Sufficient sheep were used at each grazing to defoliate the swards to the sampling height of $1 \mathrm{~cm}$ in 2-3 days. Seedling numbers of each mixture were counted in ten randomly placed $0.1 \mathrm{~m}^{2}$ quadrats per plot 6 weeks after sowing. Dry matter (DM) yields were measured at each grazing by cutting two randomly placed $0.28 \mathrm{~m}^{2}$ quadrats to $1 \mathrm{~cm}$ with hand shears. Subsamples from each plot were dissected into white clover, unsown grasses, and sown grass components to determine botanical composition. Pasture production was measured from winter 1987 until the end of autumn 1993, a period of 6 years.

\section{Results}

Data were initially examined on a season-by-season basis for each of the 6 years. The trends were similar in each year except for the tall fescue-ryegrass comparison in winter and spring.

\section{Seedling establishment}

Seedling numbers for cocksfoot and tall fescue increased linearly $(\mathrm{P}<0.001$; Figures $1 \mathrm{a}, 1 \mathrm{~b})$ as seeding rate increased to peak at 603 and 747 seedlings $/ \mathrm{m}^{2}$ respectively. Ryegrass seedling numbers were 848 seedlings $/ \mathrm{m}^{2}$ when sown alone, but numbers in mixtures were much lower than expected from the seeding rate (Negative deviations $<0.001$; Figures $1 \mathrm{a}, \mathrm{c}$ ).

\section{Ryegrass yields}

The yield of ryegrass in Ryegrass/Cocksfoot mixtures generally responded with a larger than expected yield from the inclusion of $25 \%$ ryegrass (Positive

Figure 1 The seedling number from sowing various ratios of ryegrass/cocksfoot, cocksfoot/tall fescue or tall fescue/ryegrass at 6 weeks after sowing.

a) Ryegrass/cocksfoot

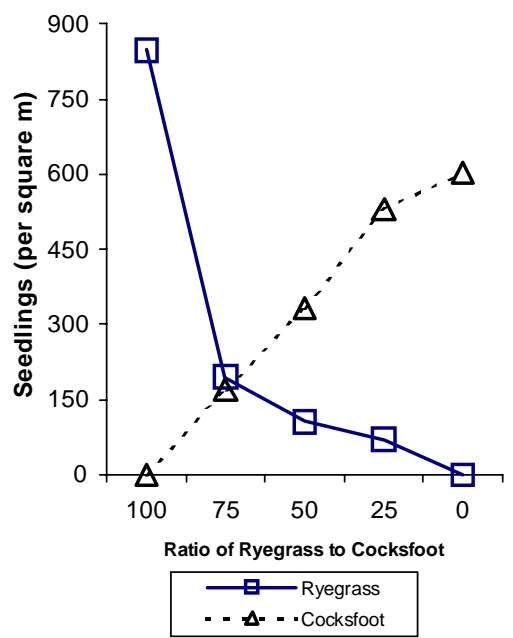

b) Cocksfoot/tall fescue

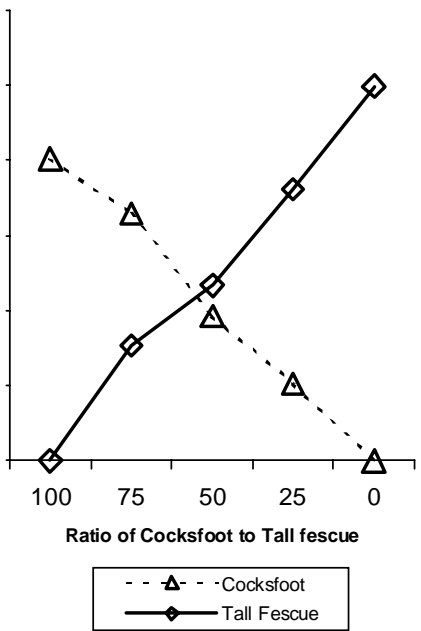

c) Tall fescue/ryegrass

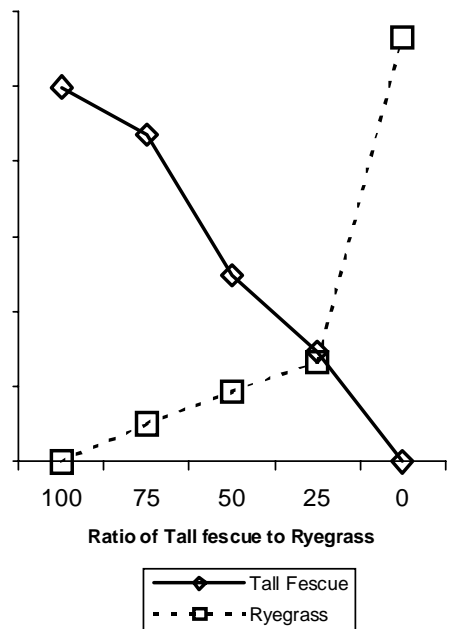


deviations $<0.05$; Figure 2). The ryegrass yield in Tall Fescue/Ryegrass mixtures generally responded by producing more ryegrass at $25 \%$ and less at $75 \%$ inclusion than expected from the sowing rate (Deviations $<0.05$; Figure 2).

\section{Cocksfoot yields}

The yield of cocksfoot when sown in Ryegrass/ Cocksfoot treatments was greater than expected at $25 \%$, and lower than expected at $75 \%$ than the seeding rates suggested (Deviations $<0.05$; Figure 2). When sown in Cocksfoot/Tall Fescue mixtures the yield of cocksfoot was high at $25 \%$ inclusion and remained high for the rest of inclusion rates, increasing only slowly between 50 and $100 \%$ (Positive deviations $<0.05$; Figure 2).

\section{Tall fescue yields}

Tall fescue yields when sown in either Cocksfoot/Tall Fescue mixtures or Tall Fescue/Ryegrass mixtures responded as expected for $25 \%$ inclusion, but yielded less than expected for 50 and $75 \%$ inclusion rates in the seeding mix (Negative deviations $<0.05$; Figure 2).

\section{Sown grass yields}

Sown grass yields of mixtures of Ryegrass/Cocksfoot decreased linearly as the amount of cocksfoot increased in the sowing mix (Linear $<0.01$; Figure 2). The sown grass yield of Cocksfoot/Tall Fescue mixtures was greater than or equal to the $100 \%$ tall fescue and cocksfoot treatments (Positive deviations $<0.05$; Figure 2). The $100 \%$ tall fescue sown grass yields were significantly greater than the $100 \%$ cocksfoot yields (Linear $<0.01$; Figure 2).

The average sown grass yield of Tall Fescue/ Ryegrass mixtures increased linearly $(\mathrm{P}<0.05)$ as the amount of ryegrass in the mixture increased (Figure 2).

\section{White clover yields}

The white clover yield was similar in all Ryegrass/ Cocksfoot and Tall Fescue/Ryegrass treatments (Figure 2). The yield of white clover in Cocksfoot/Tall Fescue mixtures was generally reduced (Negative deviations $<0.05$ ) when compared to pure sowings of either cocksfoot or tall fescue (Figure 2).

\section{Other grass yields}

Other grasses were mainly Poa annua and Bromus mollis. Annual yields of other grasses in Ryegrass/ Cocksfoot treatments were high in pure cocksfoot sowings and lower with mixtures and pure ryegrass sowings (Negative deviations $<0.05$; Figure 2). Other grass yields in Cocksfoot/Tall Fescue treatments were generally lower in mixtures than either pure cocksfoot or tall fescue sowings (Negative deviations $<0.05$; Figure 2). The combination of Tall Fescue/Ryegrass produced a linear response $(\mathrm{P}<0.01)$ as other grass

Figure 2 Mean annual yields of the botanical components and total production over 6 years.

a) Ryegrass/cocksfoot

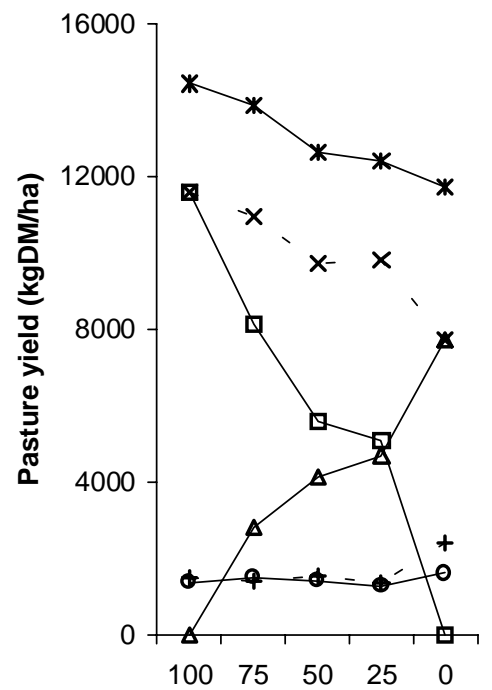

Ratio of Ryegrass to Cocksfoot b) Cocksfoot/tall fescue

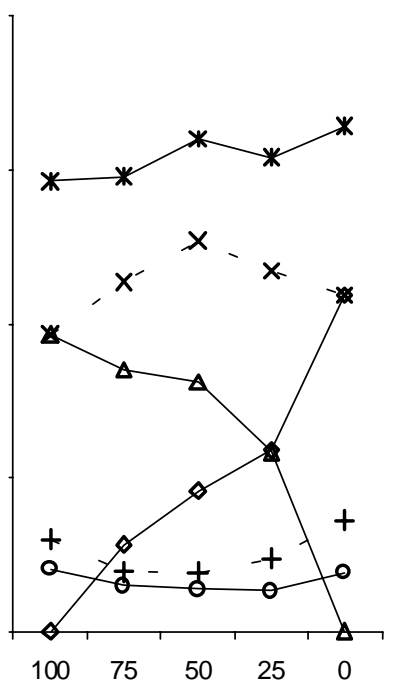

Ratio of Cocksfoot to Tall Fescue c) Tall fescue/ryegrass

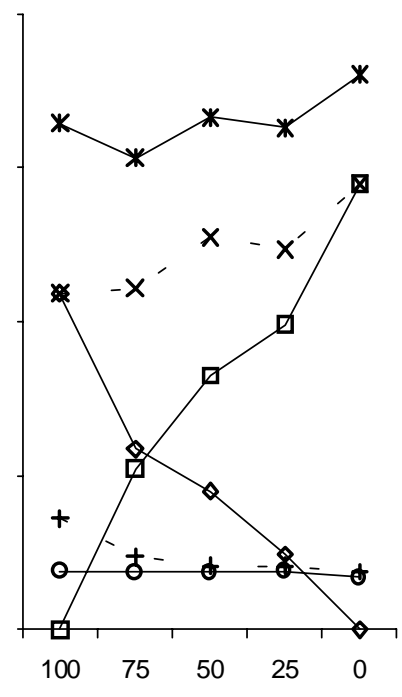

Ratio of Tall Fescue to Ryegrass

$$
\begin{aligned}
& \text { Legend: } \longrightarrow \text { Total } \quad-\overline{-}^{---} \text {Sown Grass } \quad \succ \text { Tall Fescue }
\end{aligned}
$$

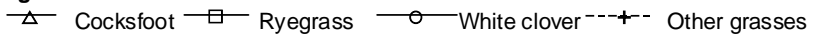


yields were lower with ryegrass. The significant deviations $(\mathrm{P}<0.05)$ indicated that other grass yields declined rapidly with the inclusion of ryegrass in the mixtures (Figure 2).

\section{Total yields}

Total dry matter yield of Ryegrass/Cocksfoot mixtures decreased linearly $(\mathrm{P}<0.001)$ as the amount of cocksfoot sown increased (Figure 2). Total dry matter yield of Cocksfoot/Tall Fescue mixtures increased linearly $(\mathrm{P}<0.01)$ as the amount of tall fescue sown increased (Figure 2). On an annual basis the total dry matter yield of Tall Fescue/Ryegrass treatments was less in mixtures than expected (Negative deviations $<0.05$ ) and was greatest for $100 \%$ ryegrass (Linear $<0.01$; Figure 2).

\section{Annual yield variation}

The year-to-year variation (Figure 3) showed a relatively constant ryegrass yield throughout, while cocksfoot and tall fescue yields improved over time. The lower sown grass and total yields in 1991/92 were the result of a cool, dry autumn.

Figure 3 Annual yields and botanical composition of the 100\% Ryegrass, Cocksfoot and Tall Fescue treatments to illustrate the year-to-year variation.

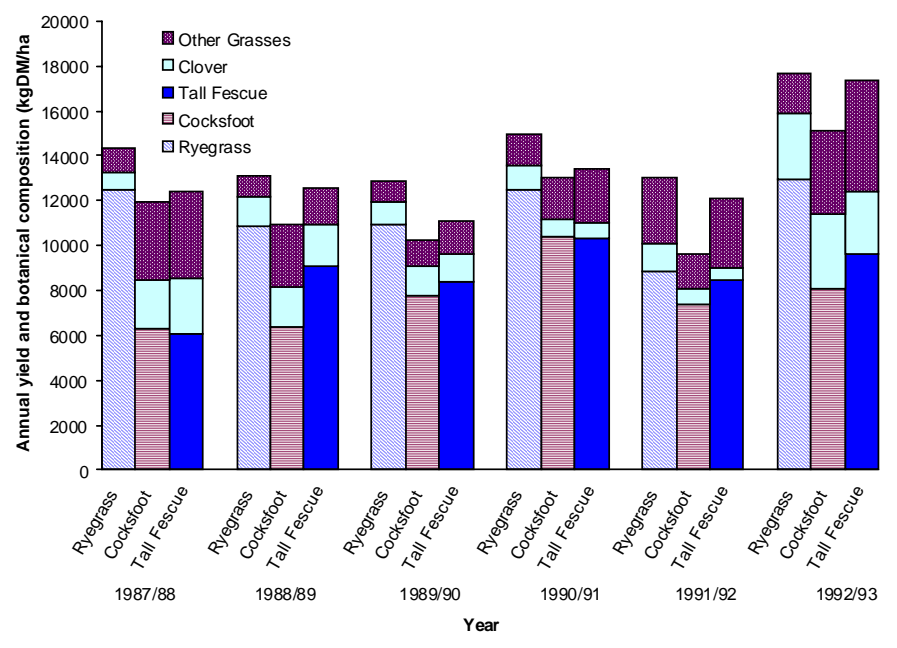

\section{Discussion}

Seedling numbers for cocksfoot and tall fescue suggested that these species started off in proportions appropriate to the original seeding rates. The ryegrass, which was drilled 6 months after the cocksfoot and tall fescue portions of the mixtures, had lower seedling establishment owing to the competition from the older companion grasses. Generally, seeding rate only influences pasture production in the short term after sowing in single species sowings (Charlton 1991; Harris et al. 1973). However, it is seeding rates that farmers have the most influence over and so the expression of the results in terms of the original seeding rates is appropriate in this context.

The annual yield data showed that both cocksfoot and tall fescue took 4 years to reach their peak production, while ryegrass was relatively constant throughout, reconfirming the early advantage of the rapid establishment of ryegrass. The perception of declining ryegrass populations with time was not supported in this trial even when cool, dry, autumn conditions prevailed in 1991/92. The increase in other grasses at this time, followed by the high clover production in 1992/93 would also suggest that a fall in soil nitrogen fertility may have played a role in the lower than average pasture production in 1991/92. Poor management of these conditions may lead to a more permanent decline in ryegrass content in onfarm conditions.

Cocksfoot was compatible with tall fescue and with ryegrass at low seeding rates. The overall performance of cocksfoot was, however, lower than either tall fescue or ryegrass, which was similar to that found by other researchers in the OtagoSouthland region (Harris et al. 1973; Stevens et al. 1992). In mixtures with tall fescue, the addition of cocksfoot increased sown grass yields. Parry et al. (1994) also found that cocksfoot/tall fescue mixtures produced more than either tall fescue or cocksfoot alone when sown without white clover. However, this was at the expense of the yields of other grasses and clover, resulting in no overall improvement in total yield. The reduction in white clover yields may be significant in the long term, especially in lower fertility soil as nitrogen fixation will be reduced by these mixtures. The increase in white clover content in 1992/93 strongly suggests that this is the case. Cocksfoot has been noted to become dominant, especially in dry conditions (Charlton \& Stewart 1999) but this was not apparent under the grazing regime used in this experiment.

Cocksfoot and ryegrass suppressed tall fescue yields. Cocksfoot yields replaced the lower yields from tall fescue. However, when mixed with ryegrass, the competition with tall fescue saw reductions in total yield. This was a direct competitive effect between the grasses, as unsown grass yield was also suppressed in mixtures, while white clover yields were unchanged.

Ryegrass was the most productive grass throughout the trial period, even in the fourth year when dry 
conditions lowered autumn and winter yields. This is comparable to results from Harris et al. (1973). The contribution of ryegrass to yield, even when the initial seedling numbers were low, indicates how aggressive and adaptable ryegrass is. The greatest effect of low initial plant numbers can be seen in mixtures of ryegrass and cocksfoot. Here the performance of the 50\% ryegrass option was distinctly lower than that expected, especially in autumn.

Moloney (1991) found that mixtures that included tall fescue and cocksfoot produced more dry matter than ryegrass alone in central North Island regions. Pure sowings of cocksfoot or tall fescue also outyielded ryegrass in the central North Island (Moloney et al. 1993). In moist North Island conditions, Hainsworth et al. (1991) and Judd et al. (1990) found that ryegrass produced more than cocksfoot or tall fescue. The overall result of relatively little advantage to mixing pasture grasses fits the model of Campbell (1990) who gave a similar classification to these three species suggesting that little extra is gained when mixed together. Vartha (1972) also found that mixtures of ryegrass and Poa trivialis produced less than ryegrass alone, and little more than Poa trivialis alone. The greatest pasture yield will be from that pasture grass which dominates in that environment.

Extra seasonal production was expected when mixing grass species that had different seasonal yields. For example cocksfoot yields in summer and autumn can be greater than ryegrass in dry conditions (Stevens et al. 1992). This was not realised and may be caused by the competition at other times of the year. Certainly, time of establishment and seed line (Eagles et al. 1982) can have an effect on the competitive ability of the sown grass.

The final factor that may have influenced the outcome of this experiment was the grazing management chosen. This was rigid and grazing intensity was always high. On-farm situations often have a variety of grazing and conservation managements. Therefore, these results with relatively little change from year to year may not hold under other defoliation managements.

\section{Conclusions}

Pasture production from ryegrass alone in this occasional drought-affected site was superior to cocksfoot, tall fescue, and any mixtures tested under the infrequent, hard-grazing regime chosen. Where cocksfoot may be required, in lower rainfall areas, hotter temperatures or pest-prone regions, then the inclusion of small amounts of ryegrass may help improve pasture yield and quality. The $25 \%$ ryegrass option had an equivalent sowing rate of $2 \mathrm{~kg} / \mathrm{ha}$ based on the number of seedlings that were counted. Tall fescue should generally be sown alone as its inclusion in mixtures reduced the yield of white clover. Generally, a farmer should decide what the pasture is needed for and the best grass to meet that objective should be sown, along with clovers and herbs which also meet the objective. Mixing temperate grasses under an infrequent, hard-grazing regime provided relatively little extra benefit for farmers in this cool-temperate environment.

\section{ACKNOWLEDGEMENTS}

The authors thank Gordon Baxter and Deborah Allen who helped complete the measurements of the experiment, and Keith and Mark Shallard who kindly donated the site and sheep for this experiment.

\section{REFERENCES}

Belgrave, B.R.; Watt, P.C.; Brock, J.L.; Wewala, S.; Sedcole, J.R. 1990. A survey of farmer knowledge and use of pasture cultivars in New Zealand. New Zealand Journal of Agricultural Research 33: 199211.

Campbell, B.D. 1990. Pasture cultivars in ecological perspective. Proceedings of the New Zealand Grassland Association 51: 139-142.

Charlton, J.F.L. 1991. Some basic concepts of pasture seed mixtures for New Zealand farms. Proceedings of the New Zealand Grassland Association 53: 3740.

Charlton, J.F.L.; Stewart, A.V. 1999. Pasture species and cultivars in New Zealand - a list. Proceedings of the New Zealand Grassland Association 61: 147166.

Eagles, C.F.; Williams, D.H.; Toler, R.J. 1982. Seasonal changes in competitive ability of contrasting populations of Dactylis glomerata. Journal of Applied Ecology 19: 555-561.

French, R.A.; Pearson, J.F.; Vartha, E.W.; Fraser, T.J. 1983. Grass grub: coping without chemical control. Proceedings of the New Zealand Grassland Association 44: 217-221.

Garnier, B.J. 1951. New Zealand Geographer 7: 43-51.

Hainsworth, R.J.; Thomson, N.A.; McCallum, D.A.; Judd, T.G. 1991. Evaluation of dryland species and new ryegrass cultivars to increase pasture productivity in coastal Taranaki. Proceedings of the New Zealand Grassland Association 53: 55-58.

Harris, A.J.; Brown, K.R.; Turner, J.D.; Johnston, J.M.; Ryan, D.L.; Hickey, M.J. 1973. Some factors affecting pasture growth in Southland. New Zealand Journal of Experimental Agriculture 1: 139-163. 
Hook, P.J. 1979. Recent advances in grassland management in eastern Southland and West Otago. Proceedings of the New Zealand Grassland Association 40: 17-24.

Judd, T.G.; Thomson, N.A.; McCallum, D.A. 1990. Pasture management and pasture species for improved dry matter production in south Taranaki. Proceedings of the New Zealand Grassland Association 51: 109-112.

Moloney, S.C. 1991. Performance of tall fescue, cocksfoot and phalaris based pastures compared with perennial ryegrass, in on-farm trials. Proceedings of the New Zealand Grassland Association 53: 41-46.

Moloney, S.C.; Lancashire, J.A.; Barker, D.J. 1993. Introduction, production and persistence of five grass species in dry hill country 7. Central Plateau, North Island, New Zealand. New Zealand Journal of Agricultural Research 36: 49-59.

New Zealand Meteorological Service, 1970. Rainfall Summary: 1941-1970.

Parry, F.J.; Lucas, R.J.; McKenzie, B.A. 1994. Early productivity of binary mixtures and single grass species. Proceedings of the New Zealand Grassland Association 56: 205-208.
Sithamparanathan, J. 1979. Seasonal growth patterns of herbage species on high rainfall hill country in northern North Island. 1. Temperate grasses. New Zealand Journal of Experimental Agriculture 7: 157-162.

Stevens, D.R.; Baxter, G.S.; Stewart, A.; Casey, M.J.; Miller, K.B. 1992. Grasslands Kara cocksfoot: a productive cultivar under lax grazing. Proceedings of the New Zealand Grassland Association 54: 143146.

Taylor, N.H.; Pohlen, I.J. 1968. Classification of New Zealand Soils. In: New Zealand Soil Bureau: Soils of New Zealand, Part 1, Chapter 2. Ed. Luke, J. New Zealand Soil Bureau Bulletin 26(1), Wellington.

Vartha, E.W. 1972. Effect of Poa trivialis L. on growth of perennial ryegrass and white clover. New Zealand Journal of Agricultural Research 15: 620-628.

Vartha, E.W. 1975. Comparative annual and seasonal growth of three ryegrass varieties and cocksfoot at Lincoln, Canterbury. New Zealand Journal of Experimental Agriculture 3: 319-323. 